\title{
Sliding Mode Controller Design For Direct Self Control of Induction Motor For Traction Drive Applications
}

\author{
E.E. El-Kholy*, Abdou. M. El-refay **, F. El-Kady**, and S. A. Mahmoud* \\ * :Electrical Engineering Department, Faculty of Engineering, Shebin El-Kom, \\ Minufiya University. \\ ** :Elect. Tech. Dept., Industrial Education College (IEC), Cairo.
}

\begin{abstract}
:
A control system with fast torque response is important in traction drive applications, where direct self control is highly desirable. A direct self control (DSC) of induction motor is presented using a sliding mode controller. The instantaneous values of the flux and torque are calculated from only the primary variables and controlled in a hysteresis band fashion. In this system the errors in the torque and flux along with the flux position are directly used to choose the optimized switching states of the base drive circuit. New torque and flux controllers are proposed to improve the dynamic response of the drive system. The results demonstrate the superior performance of such a drive system.
\end{abstract}

\section{KEYWORDS:}

Direct self control- Induction motor- Space vector modulation.

\section{INTRODUCTION:}

Many applications, such as traction drives, require fast torque control. DC motors has dominated the area of drive technology for some particular applications that need high dynamic performance[1]. With recent advances in power electronics and in microprocessors, variable-frequency and variablevoltage induction motor drives have come into increased use in various industry applications.

Manuscript received from Dr; E. E. El-kholy on : 12/8/1999

Accepted on: 12/9/1999

Engineering Research Bulletin, Vol 22,No 3, 1999

Minufiya University, Faculty of Engineering, Shebin El-Kom, Egypt, ISSN 1110-1180 
In traction applications, such as diesel-electric locomotives or all electric automobiles, torque is directly controlled, that is, torque is the commanded signal and not the result of speed error[2,3]. Therefore, there is a growing interest in developing simpler torque control structure without sacrificing the dynamic performance. Direct self control is well suited to this type of application as the instantaneous values of the torque and flux are calculated from only the primary variables and then regulated to their commanded values by selecting the switching states of the inverter which gives the proper torque and flux.

In this paper a space vector pulse width modulation voltage source inverter is used to drive the induction motor. The torque and flux controller design will be investigated, using a sliding mode controller for direct self control. The realization of excellent dynamic torque and flux response is presented.

\section{CONTROL SYSTEM CONFIGURATION:}

A detailed block diagram of the direct self controlled induction motor drive is shown in Fig.(1); which shows the quick response torque control system in which the instantaneous speed $\left(\omega_{s}\right)$ of the primary flux linkage vector $\left(\psi_{s}\right)$ of the motor is controlled to allow the developed torque $\left(\mathrm{T}_{\mathrm{d}}\right)$ to agree with the torque command $\left(\mathrm{T}^{*}\right)$ within a certain error. $\psi_{s}$ and $T_{d}$ are calculated respectively by the following relations[4];

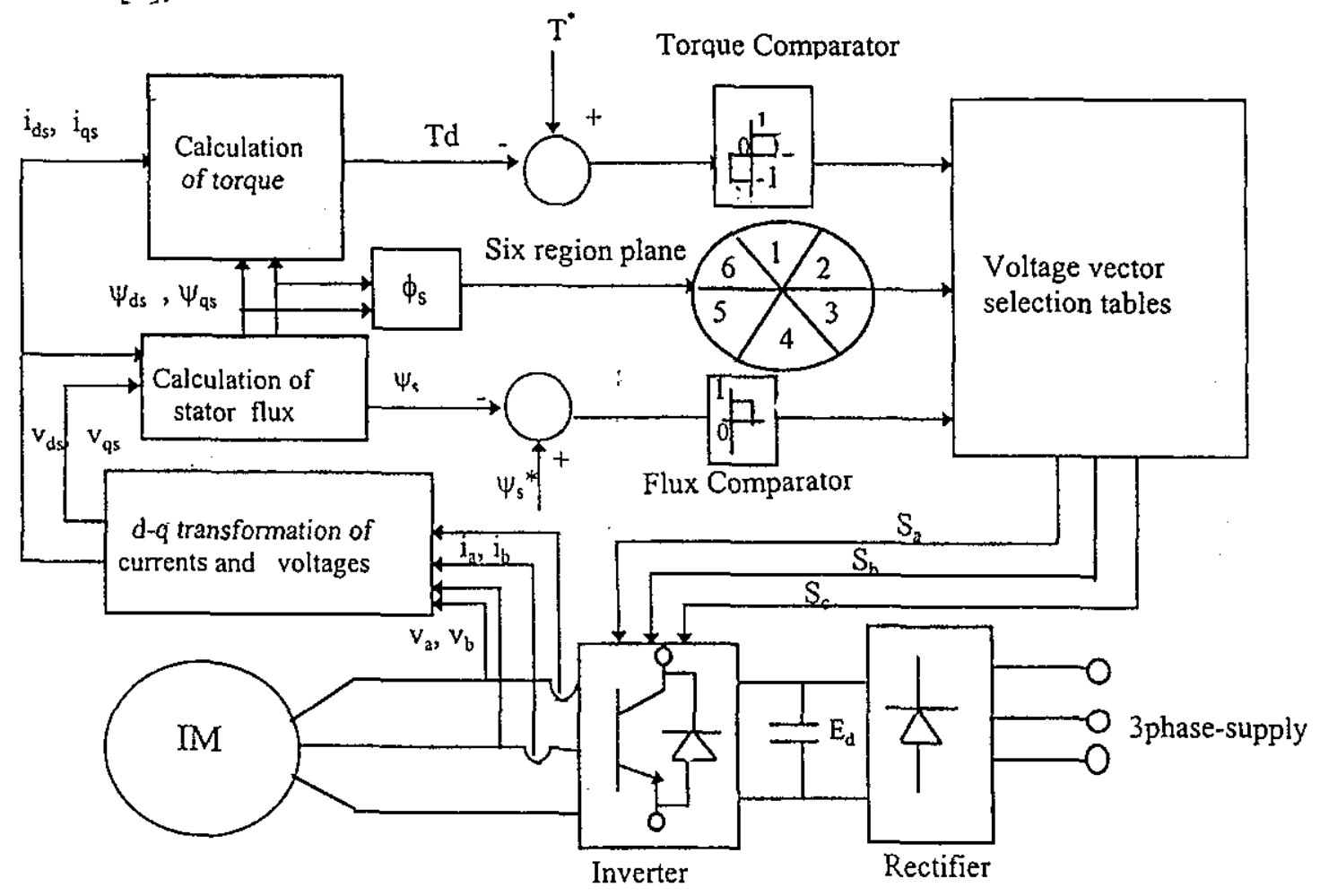

Fig.(1) Schematic diagram of direct self control system 
$\psi_{s}=\int\left(\mathrm{v}_{\mathrm{s}}-\mathrm{R}_{\mathrm{s}} \mathrm{i}_{\mathrm{s}}\right) \mathrm{dt}$

$T_{d}=\frac{3}{2} p\left(\psi_{d s} i_{q s}-\psi_{q s} i_{d s}\right)$

where,

$\mathrm{V}_{\mathrm{s}}$ the instantaneous space primary voltage vector.

$i_{s} \quad$ the instantaneous space primary current vector.

$\mathrm{R}_{\mathrm{S}} \quad$ the primary winding resistance.

$\psi_{\mathrm{ds}} \quad$ d-axis stator flux.

$\psi_{\mathrm{qs}} \quad \mathrm{q}$-axis stator flux.

$i_{d s} \quad d$-axis stator current.

$i_{q s} \quad q$-axis stator current.

From equation(1), it is clear that $\psi_{\mathrm{s}}$ can be directly controlled by $\mathrm{v}_{\mathrm{s}}$ because of the stator winding resistance drop is small. It is generally known that there are eight voltages made by a three-phase inverter. By proper selecting of these vectors both the amplitude and speed of $\psi_{s}$ are controlled to regulate the instantaneous value of $T_{d}$ as it will be shown later.

\section{DIRECT SELF CONTROL MODELING:}

For the purpose of control design, it is necessary to know a dynamic model of the induction motor, which incorporates all dynamic effects occurring during steady state and transient operation. The state equations of the induction motor are given by[5].

$\left[\begin{array}{c}\frac{d i_{d s}}{d t} \\ \frac{d i_{q s}}{d t} \\ \frac{d i_{d r}}{d t} \\ \frac{d i_{q r}}{d t}\end{array}\right]=\left[\begin{array}{c}\frac{1}{\sigma L_{s}} V_{d s} \\ \frac{1}{\sigma L_{s}} V_{q s} \\ -\frac{L_{m}}{\sigma L_{s} L_{r}} V_{d s} \\ -\frac{L_{m}}{\sigma L_{s} L_{r}} V_{q s}\end{array}\right]+\left[\begin{array}{cccc}-\frac{R_{s}}{\sigma L_{s}} & \frac{L_{m}^{2} p \omega_{r}}{\sigma L_{s} L_{r}} & \frac{R_{s} L_{m}}{\sigma L_{s} L_{r}} & \frac{L_{m} p \omega_{r}}{\sigma L_{r}} \\ -\frac{L_{m}^{2} p \omega_{r}}{\sigma L_{s} L_{r}} & -\frac{R_{s}}{\sigma L_{s}} & -\frac{L_{m} p \omega_{r}}{\sigma L_{r}} & \frac{L_{m} R_{s}}{\sigma L_{s} L_{r}} \\ \frac{R_{s} L_{m}}{\sigma L_{s} L_{r}} & -\frac{L_{m} p \omega_{r}}{\sigma L_{r}} & -\frac{R_{r}}{\sigma L_{r}} & -\frac{\omega_{r}}{\sigma} \\ \frac{L_{m} p \omega_{r}}{\sigma L_{r}} & \frac{L_{m} R_{s}}{\sigma L_{s} L_{r}} & \frac{\omega_{r}}{\sigma} & -\frac{R_{r}}{\sigma L_{r}}\end{array}\right]\left[\begin{array}{c}i_{d s} \\ i_{q s} \\ i_{d r} \\ i_{q r}\end{array}\right]$

where;

$\mathrm{L}_{\text {is }} \quad$ stator winding leakage inductance per phase.

$\mathrm{L}_{\mathrm{lr}} \quad$ rotor winding leakage inductance per phase.

$\mathrm{L}_{\mathrm{m}} \quad$ mutual inductance per phase referred to the stator.

$\sigma \quad$ total equivalent leakage factor of the $\operatorname{motor}\left(\sigma=1-\frac{\mathrm{L}_{\mathrm{m}}^{2}}{\mathrm{~L}_{\mathrm{s}} \mathrm{L}_{\mathrm{r}}}\right)$.

Ls stator winding inductance per phase $\left(\mathrm{Ls}=\mathrm{L}_{1 s}+\mathrm{L}_{\mathrm{m}}\right)$.

$\mathrm{L}_{\mathrm{r}}$ rotor winding inductance per phase $\left(\mathrm{L}_{\mathrm{r}} \mathrm{L}_{\mathrm{lr}}+\mathrm{L}_{\mathrm{m}}\right)$. 
The instantaneous space vectors of the pulse width modulation inverter are regarded as discrete values, and the analysis using the instantaneous vectors is suitable for investigating the dynamic behavior of the motor. To treat three phase quantities as a whole, the three phase machine voltages and currents are represented by an instantaneous space voltage vector $\left(\mathrm{v}_{\mathrm{s}}\right)$ and an instantaneous space current vector $\left(i_{s}\right)$, respectively, that is $[6]$ :

$$
\begin{aligned}
& v_{s}=\sqrt{\frac{2}{3}}\left[v_{a}+v_{b} e^{j \frac{2 \pi}{3}}+v_{c} e^{j \frac{4 \pi}{3}}\right] \\
& i_{s}=\sqrt{\frac{2}{3}}\left[i_{a}+i_{b} e^{j \frac{2 \pi}{3}}+i_{c} e^{j \frac{4 \pi}{3}}\right]
\end{aligned}
$$

where, $v_{a}, v_{b}$ and $v_{c}$ are the instantaneous values of the primary line-to-neutral voltages and $i_{a}, i_{b}$ and $i_{c}$ are the instantaneous values of the primary line-to-neutral currents. Schematic diagram of the pulse width modulation fed induction motor drive is shown in Fig.(2), where $S_{a}, S_{b}$, and $S_{c}$ are the switching functions with the value of 1 when the switch is set to the positive voltage or 0 when the switch is set to the negative voltage.

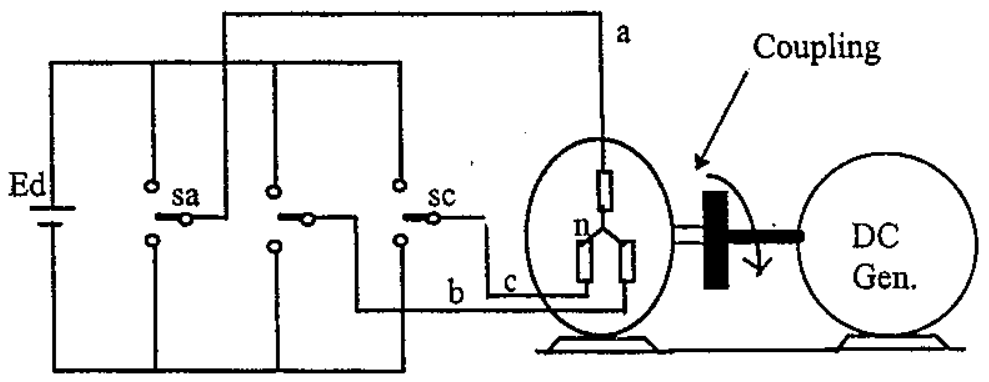

Fig.(2 ) Schematic diagram of PWM inverter fed induction motor drive.

Considering the combinations of the status of switches, the inverter has eight conduction modes[7,8]. By using these switching functions the primary space voltage vector can be expressed as;

$\mathrm{v}_{\mathrm{s}}\left(S_{a}, S_{b}, S_{c}\right)=\sqrt{\frac{2}{3}} E_{d}\left(S_{a}+S_{b} \mathrm{e}^{\mathrm{j} \frac{2 \pi}{3}}+S_{c} \mathrm{e}^{\mathrm{j} \frac{4 \pi}{3}}\right)$

where, $E_{d} \quad$ is the dc link voltage of the inverter.

According to the combinations of switching modes, the primary space voltage vectors $v_{s}\left(S_{a}, S_{b}, S_{c}\right)$ is specified for eight kinds of vectors $v_{s}(1,1,1)$, $(0,0,0)$ and the others are the space nonzero active voltage vectors. i.e. $(1,0,0), \ldots \ldots \ldots . .(0,1,1)$, as shown in Fig.(3) according to the table(1) listed below. 
Table (1)

\begin{tabular}{|c|c|c|c|c|c|c|c|c|}
\hline $\begin{array}{c}\text { N(switching } \\
\text { mode) }\end{array}$ & 1 & 2 & 3 & 4 & 5 & 6 & 7 & 8 \\
\hline phase-a & 1 & 0 & 0 & 0 & 1 & 1 & 1 & 0 \\
\hline phase-b & 1 & 1 & 1 & 0 & 0 & 0 & 1 & 0 \\
\hline phase-c & 0 & 0 & 1 & 1 & 1 & 0 & 1 & 0 \\
\hline
\end{tabular}

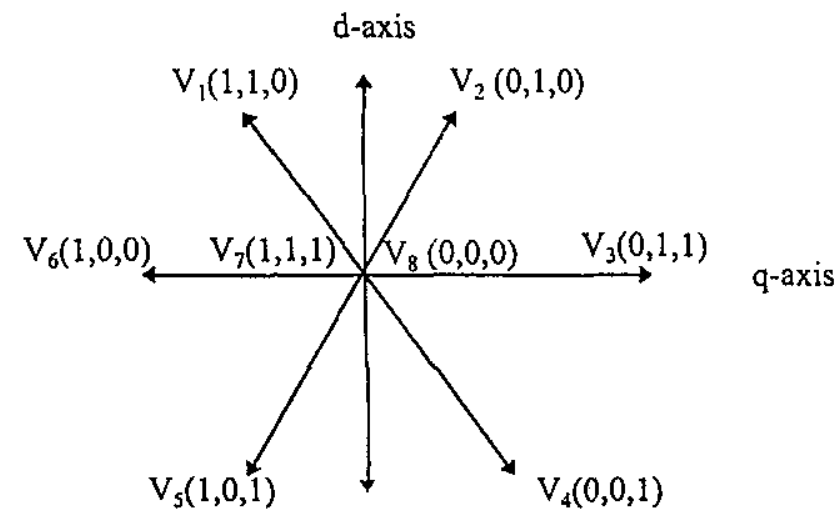

Fig.(3) Representation of primary space voltage vectors.

\section{DIRECT SELF CONTROL STATE VARIABLES SELECTION:}

The direct self control is achieved using three state variables[9]. The first variable is the difference between the command stator flux and the estimated stator flux magnitude, the second state variable is the difference between the command torque and the estimated electromagnetic torque, the third one is the angle of stator flux. The control variables of the direct self control can be investigated using Fig.(4-a), Fig.(4-b) as follows. Looking at the flux position in Fig (4-a) it is noticed that, states $3,4,5$ will increase the flux while states $2,1,6$ will decrease it. Similarly, states $4,3,2$ will increase the current (i.e. the torque) while states $1,6,5$ will decrease it. Gathering these states, it is found that for a large increase in flux and a small increase in torque, state 4 is selected, for a small increase in flux and a large increase in torque, state 3 is selected, for a small decrease in flux and a small increase in torque, state 2 is selected, for a large decrease in flux and a small decrease in torque, state 1 is selected, for a small decrease in flux and a large decrease in torque, state 6 is selected, for a small increase in flux and a large decrease in torque, state 5 is selected, and for a small decrease in torque and a constant flux, state 0 is selected. 


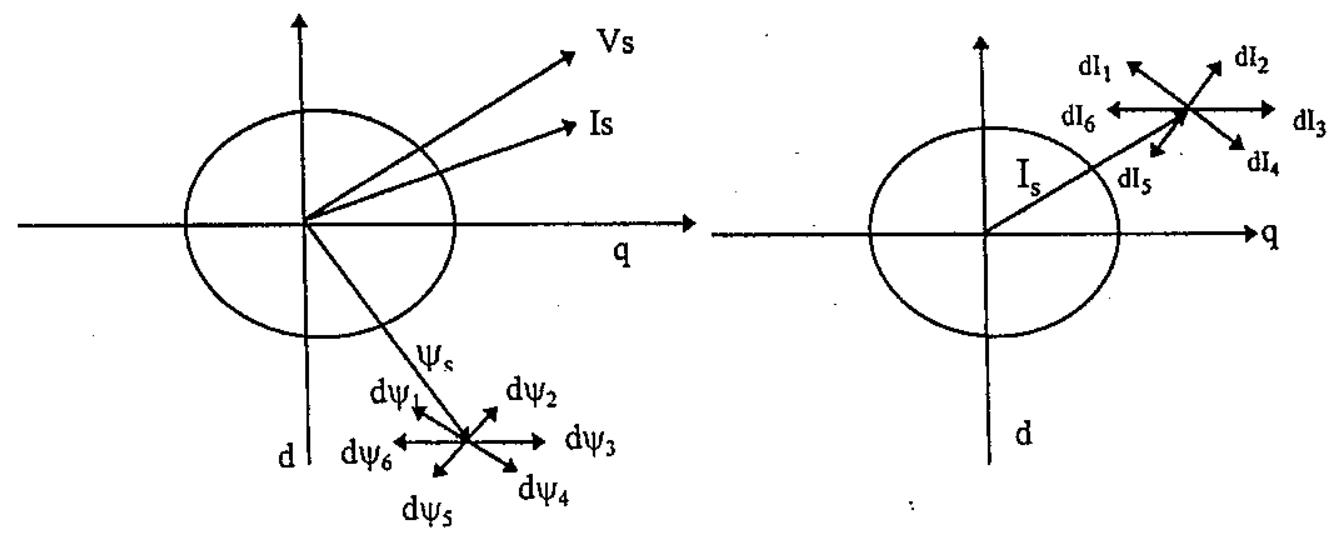

(a)

(b)

Fig.(4) Vector diagram illustrating the state selection process of flux and torque during transient operation.

\section{SLIDING MODE DIRECT FLUX AND TORQUE CONTROLLER DESIGN:}

In order to achieve a high level of ac motor control it is necessary to keep flux as nearly as constant except for the field weakening region $[3,4]$. In the case of sinusoidal ac power supplies the trajectory of primary flux is a smooth circle unlike, in the electronic inverters, it is not purely sinusoidal, it is therefore difficult to keep the air gap flux constant especially in the low speed region. The instantaneous space vector approach has made it possible to trace the primary flux and keep it almost constant. The primary space flux vector of induction motor can be calculated by equation(1). Assuming that the voltage drop of the primary winding resistance is small, the trajectory of $\psi_{s}$ moves in the direction of $v_{s}\left(S_{a}, S_{b}, S_{c}\right)$, the velocity of space non zero voltage vector gives the direction and the amplitude of $\psi_{s}$, but by applying a space zero voltage vector to an induction motor, the movement of $\psi_{s}$ will be stopped. Therefore, by selecting these vectors appropriately, the trajectory of $\psi_{\mathrm{s}}$ will follow the specified locus. i.e. by selecting adequate voltage vectors, $\psi_{\mathrm{s}}$ can be kept almost constant and the rotating velocity of $\psi_{\mathrm{s}}$ can be controlled by changing the output ratio between zero . vectors and the remaining non zero vectors. So, $\omega_{\mathrm{s}}$ and $\psi_{\mathrm{s}}$ are greatly concerned with the direct self control. In DSC system under study, constant flux can be obtained by comparing the primary flux with the command flux. The output of the flux comparator will be as follows;

$\varepsilon \psi=1$ when $\psi_{s}<\psi_{s}{ }^{*}$, and

$\varepsilon \psi=0$ when $\psi_{s}>\psi_{s}^{*}$.

where, $\varepsilon$ denote the error signal in both $\psi_{\mathrm{s}}$ and $\mathrm{T}_{\mathrm{d}}$. 
In the six step inverter the $\mathrm{d}-\mathrm{q}$ plane can be divided into six regions resulting from the general case;

$$
(2 \mathrm{~N}-3) \pi / 6=<\phi_{\mathrm{n}}<=(2 \mathrm{~N}-1) \pi / 6 \quad \text { where; } \mathrm{N}=1,2, \ldots \ldots 6 \text {. }
$$

Since the flux is kept almost constant, the torque is then proportional to $\omega_{s}$ (instantaneous-slip angular velocity). As mentioned above, the velocity of the primary flux is proportional to the de link voltage, and the direction of rotation of the primary flux is determined by the active voltage vectors and the movement of the primary flux will be stopped when zero voltage vectors is applied. Therefore, by changing the ratio of the number of active and zero voltage vectors, the slip angular velocity can be regulated. Hence, the direct torque control is obtained by adequate selection between active and zero voltage vectors. Hence, when the torque $T_{d}$ is small compared with $T^{*}$ it is necessary to increase $T_{d}$ as fast as possible by applying the fastest $\omega_{s}$. On the other hand, when $T_{d}$ reaches $T^{*}$ it is better to decrease $T_{d}$ as slowly as possible. Thus the output of the torque controller can be classified as follow;

$$
\begin{aligned}
& \varepsilon \mathrm{T}=1 \text { if } \mathrm{T}_{\mathrm{d}}<\mathrm{T}^{*} \\
& \varepsilon \mathrm{T}=0 \text { if } \mathrm{T}_{\mathrm{d}}=\mathrm{T}^{*} \\
& \varepsilon \mathrm{T}=-1 \text { if } \mathrm{T}_{\mathrm{d}}>\mathrm{T}^{*}
\end{aligned}
$$

The output of the torque controller is a three level hysteresis comparator. Using the three variables, $\varepsilon \psi, \varepsilon T$ and the stator flux position $\phi=\left(\tan ^{-1} \psi_{\mathrm{d}} / \psi_{\mathrm{q}}\right)$, the following optimum switching tables (2), and (3) will be created. Accordingly, accessing the tables, in which the inverter output voltage are given by the outputs of the two comparators and the angle $\phi(n)$. The optimum switching model (base drive signals) desirable for driving the base of the inverter can be obtained.

Table (2)

\begin{tabular}{|c|c|l|l|l|l|l|l|}
\hline$\varepsilon \psi$ & $\varepsilon \mathrm{T}$ & $\phi_{1}$ & $\phi_{2}$ & $\phi_{3}$ & $\phi_{4}$ & $\phi_{5}$ & $\phi_{6}$ \\
\hline 0 & 1 & $\mathrm{~V}_{2}$ & $\mathrm{~V}_{3}$ & $\mathrm{~V}_{4}$ & $\mathrm{~V}_{5}$ & $\mathrm{~V}_{6}$ & $\mathrm{~V}_{1}$ \\
\hline 0 & 0 & $\mathrm{~V}_{8}$ & $\mathrm{~V}_{7}$ & $\mathrm{~V}_{8}$ & $\mathrm{~V}_{7}$ & $\mathrm{~V}_{8}$ & $\mathrm{~V}_{7}$ \\
\hline 0 & -1 & $\mathrm{~V}_{4}$ & $\mathrm{~V}_{5}$ & $\mathrm{~V}_{6}$ & $\mathrm{~V}_{1}$ & $\mathrm{~V}_{2}$ & $\mathrm{~V}_{3}$ \\
\hline
\end{tabular}

Table (3)

\begin{tabular}{|c|c|l|l|l|l|l|l|}
\hline$\varepsilon \psi$ & $\varepsilon \mathrm{T}$ & $\phi_{1}$ & $\phi_{2}$ & $\phi_{3}$ & $\phi_{4}$ & $\phi_{5}$ & $\phi_{6}$ \\
\hline 1 & 1 & $\mathrm{~V}_{1}$ & $\mathrm{~V}_{2}$ & $\mathrm{~V}_{3}$ & $\mathrm{~V}_{4}$ & $\mathrm{~V}_{5}$ & $\mathrm{~V}_{6}$ \\
\hline 1 & 0 & $\mathrm{~V}_{7}$ & $\mathrm{~V}_{8}$ & $\mathrm{~V}_{7}$ & $\mathrm{~V}_{8}$ & $\mathrm{~V}_{7}$ & $\mathrm{~V}_{8}$ \\
\hline 1 & -1 & $\mathrm{~V}_{5}$ & $\mathrm{~V}_{6}$ & $\mathrm{~V}_{1}$ & $\mathrm{~V}_{2}$ & $\mathrm{~V}_{3}$ & $\mathrm{~V}_{4}$ \\
\hline
\end{tabular}


The inverter output voltage is then defined as in equation (6). The entire system has been verified using Matlab, Simulink and the following simulation results has been obtained.

\section{SIMULATION RESULTS:}

The control system developed has been implemented in a computer simulation program, modeling the two subsystem induction motor and control algorithm. The controller simulation uses the parameters of an experimental laboratory prototype. These parameters are listed in the Appendix. The graphs shown in Fig.(5) show the response of the system with a torque command of 4 N.m. The transient and steady state flux vector in Fig.(5-a) shows nearly a circular path indicating a good flux regulation. The electromagnetic torque shown in Fig.(5-b) is close to the commanded value, while the time taken for the torque reach its commanded value is about $0.02 \mathrm{Sec}$., ensuring good dynamic torque response. Fig. (5-c) shows the stator currents in phase $\mathrm{a}, \mathrm{b}$ and $\mathrm{c}$ which are nearly sinusoidal. Fig.(5-d) shows the waveforms of stator currents in d-q axis, it is noticed that the phase shift between them equal $90^{\circ}$.

Figure(6) shows the response of the system for a step change in torque from 3 N.m. to 7 N.m. keeping the flux command constant. Fig.(6-a) shows the steady state stator flux, which demonstrates an excellent dynamic flux control under changed command torque. Fig.(6-b) shows the developed torque which is enclosed to a commanded value of $3 \mathrm{~N} . \mathrm{m}$. region or $7 \mathrm{~N} . \mathrm{m}$. region. The three phase stator currents are shown in Fig.(6-c). It is clear that, these stator currents are changed at the instant of changing the command torque and fastly retrieve their steady state values.

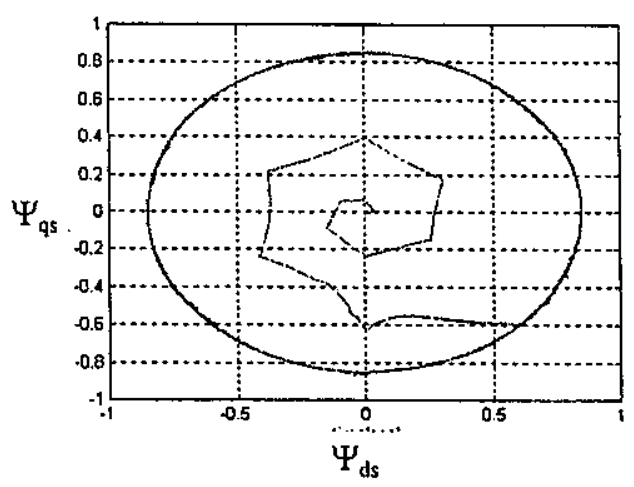

Fig. (5-a) Stator flux.

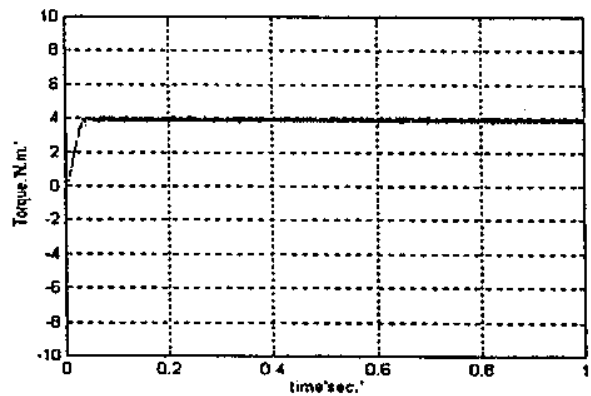

Fig. (5-b) Electromagnetic torque. 


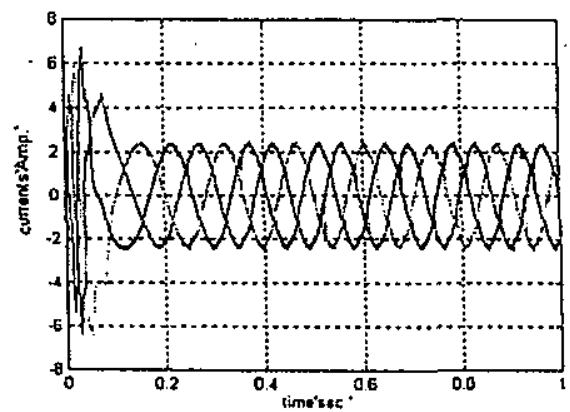

Fig. (5-c) Stator currents.

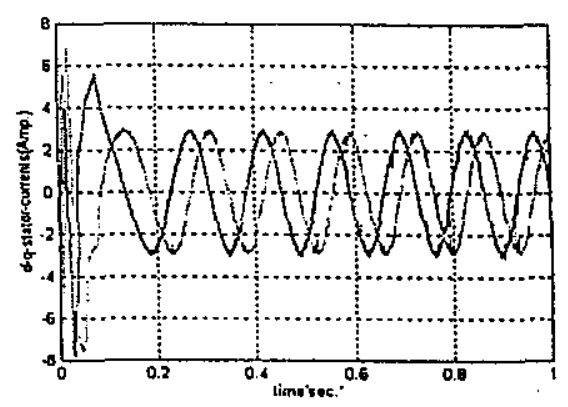

Fig. (5-d) d-q axis stator current.

Figure(7) shows simulation results in which a step response of the system is studied at a step change of command torque from $3 \mathrm{~N} . \mathrm{m}$. to its $7 \mathrm{~N} . \mathrm{m}$. at 0.4 $\mathrm{Sec}$, then, at $0.8 \mathrm{Sec}$. the command torque is decreased to its initial value (3 N.m.). Behavior of developed torque shows clearly that the response of the torque is as quickly as possible as shown in Fig.(7-b). As can be seen from Fig.(7-c), it is clear that, the stator currents in phases $a, b$, and $c$ are changing according to the variation of the command torque.

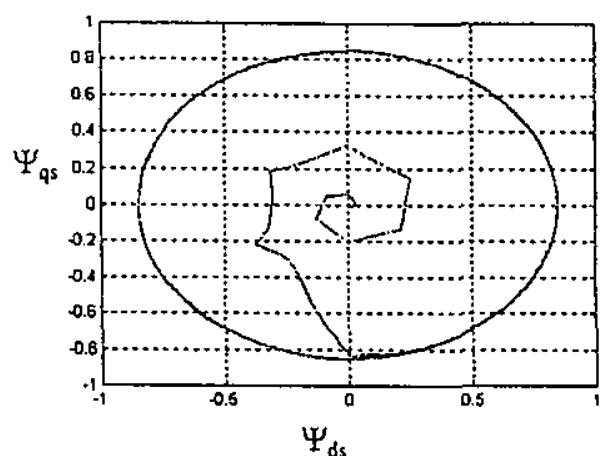

Fig. (6*a) Stator flux.

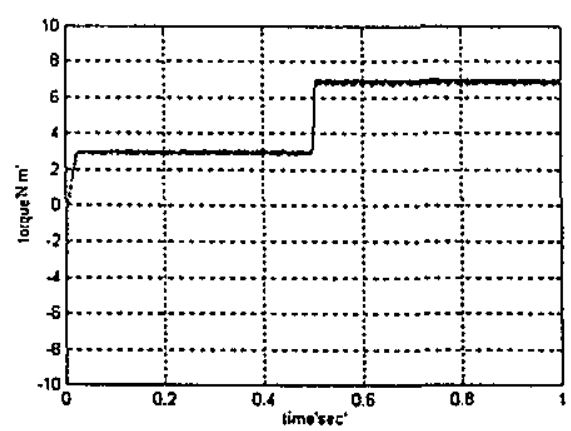

Fig. (6-b) Electromagnetic torque.

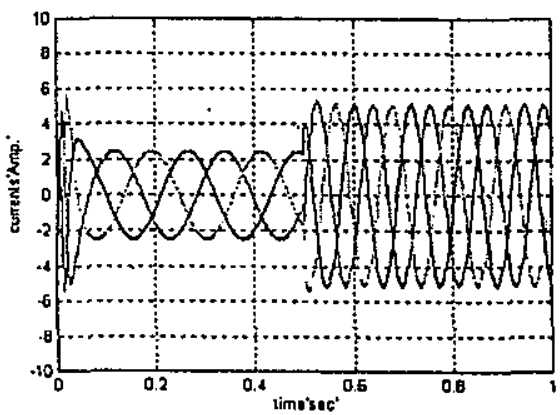

Fig. (6-c) Stator currents.

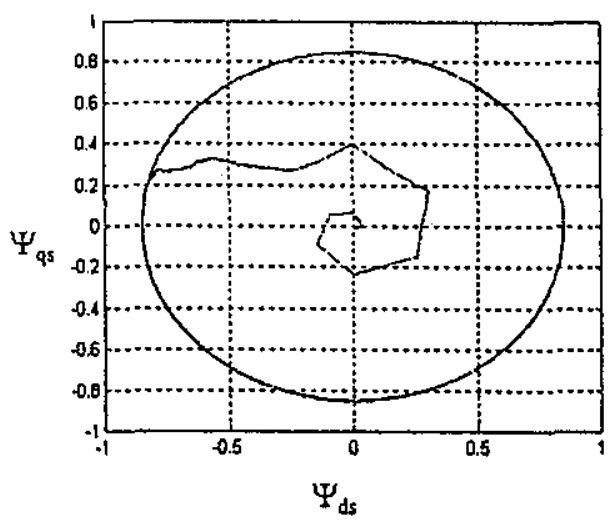

Fig.(7-a) Stator flux. 


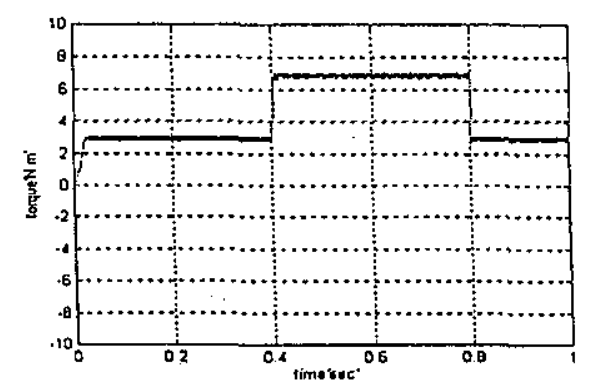

Fig. (7-b)Electromagnetic torque

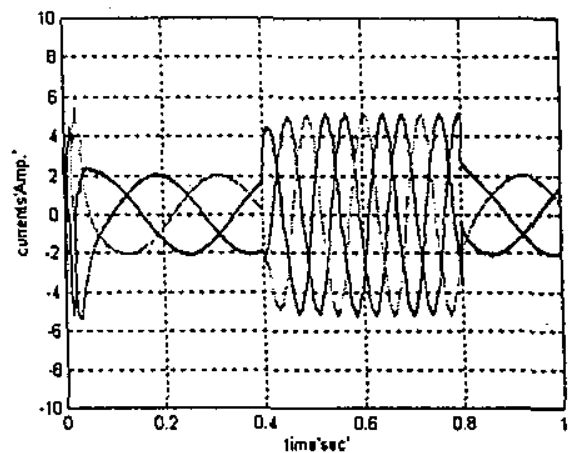

Fig. (7-c) Stator currents.

\section{CONCLUSION:}

This paper presents a torque and flux controller design for a direct self controlled induction motor fed from space vector modulation. The proposed control scheme generates switching sequence of the modulation by using instantaneous values of stator flux, torque and angle of stator flux. The proposed control scheme can achieve fast transient response and, at the same time, have very low ripple in the output current during steady state operation. The simulation results show that the fast and highly dynamic torque response can be obtained by direct self control techniques. Future experimental implementation of the drive system is under progress in the Electrical Drive Research Laboratory at Elect. Eng. Dept., Minufiya University.

\section{APPENDIX:}

The induction motor is a three-phase squirrel cage and has the following data;

$\begin{array}{ll}\text { Rated power } & : 1.1 \mathrm{kw} \\ \text { Rated line voltage } & : 380 \mathrm{volts} \\ \text { No. of pair poles } & : 2 \\ \text { Stator resistance } & : 7.4826 \mathrm{ohm} \\ \text { Rotor resistance } & : 3.6840 \mathrm{ohm} \\ \text { Mutual inductance } & : 0.4114 \text { henry } \\ \text { Stator leakage inductance } & : 0.0221 \text { henry } \\ \text { Rotor leakage inductance } & : 0.0221 \text { henry } \\ \text { Moment of inertia } & : 0.004 \mathrm{Kg} . \mathrm{m}^{2} \\ \text { Supply frequency } & : 50 \mathrm{~Hz} . \\ \text { Motor speed } & : 1400 \mathrm{r.p} . \mathrm{m} . \\ \text { Rated load torque } & : 7.5 \mathrm{~N} . \mathrm{m} .\end{array}$




\section{REFERENCES:}

[1] M. Depenbrock, "Direct Self Control (DSC) of Inverter-fed Induction Motors" IEEE Transaction Power Electronics, Vol. 3, No. 4, pp. 420-429, October1988.

[2] T. G. Habetler, F. Profumo, and M. Pastorellil, "Direct Torque Control of Induction Machines Over a Wide Speed Range" IEEE-IAS- Annual Meeting Conference Record, pp. 600-606, 1992.

[3] Y. H. Lio, C. L. Chen, and R. J. Tu, " A Novel Space-Vector Current Regulation Scheme for a Field-Oriented-Controlled Induction Motor Drive" IEEE Transaction Industrial Electronics, Vol. 45, No. 5, pp. 730-737, October 1998.

[4] M. P. Kazmierkowski, and A. B. Kasprowicz, "Improved Direct Torque and Flux Vector Control of PWM Inverter-Fed Induction Motor Drives" IEEE Transaction Industrial Electronics, Vol. 42, No. 4, pp. 344-349, August 1995.

[5] U. Baader, M. Depenbrock, and G. Gierse, "Direct Self Control (DSC) of Inverter-Fed Induction Machine A Basis for Speed Control Without Speed Measurement" IEEE Transaction Industry Applications, Vol. 28, No.3, pp. 581-588, May/June 1992.

[6] T. G. Habetler, F. Profumo, M. Pastorelli, and L. M. Tolbert, "Direct Torque Control of An Induction Machines Using Space Vector Modulation" IEEE Transaction Industry Applications, Vol. 28, No. 5, pp. 1045-1053, September/October 1992.

[7] A. Takano, " Quick-Response Torque-Controlled Induction Motor Drives Using Phase-Locked Loop Speed Control With Disturbance Compensation" IEEE Transaction on Industrial Electronics, Vol. 43, No. 6, pp. 640-646, December 1996.

[8] V. Vlatkovic, and D. Borojevic, "Digital-Signal-Processor-Based Control of Three-Phase Space Vector Modulated Converters" IEEE Transaction on Industrial Electronics, Vol. 41, No. 3, June 1994.

[9] T. G. Habeteler, and D. M. Divan, "Control Strategies for Direct Torque Control Using Discrete Pulse Modulation" IEEE Transaction Industry Applications, Vol. 27, No. 5, pp. 893-901, September/October 1991. 


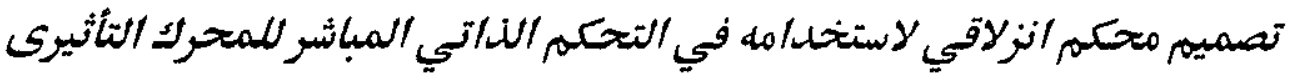 المستخلسمفي تطبيقات الحر}

نظرا لأهمية الحصول على إستجابه سرية للعزم لنظمى التحكم في تطبيقات التسيير في الجر الكهربي فأن التحكمم الداتي المباشر يتبر من التطبيقـات الهامـة و المرغوب فيها • يعرض هذا البحث اقتراح وتصميم محكمم للعزم والتدفق بغرض التحكم الذاتي المباشر في محرب تأثيري مغذى من تحديـل متحبه الفراغ باستخدام محكمى انزلاقي. حيـث يولس نظـام التحكسم المقـترح تتـابع فتـح وغلـق المفــيح الإلمكترونية لمخير النبضات معدلة الاتساع بنرض التعديل باستخدام قيمة كل من التدفق والعزم اللحظية وأيضا زاوية تدفق العضو الثابت • يحقق نظام التحكمى المقترح إستجابه سـريعة للحـالات العابرة مثل زيادة ونقصان حمل الأله بشكل مفاجئ وبالإضافة لذلك فإن التيار المغنى للمحرد أثناء التشغيل في الحالة المستقرة يقترب كثيرا مـن الشكل الجيبى فضلا عن أنه يمتاز بقلة التموجات فيه. من النتائج يتبين أنه من الممكن الحصول على الأستجابه الديناميكية السريتة للعزم بواسطة التحكم المقترح · 